\title{
SAMEVATTENDE RESOLUSIES
}

B.J. VAN DER WALT, Instituut vir Reformatoriese Siudies, Potchefstroom

\section{ABSTRACT}

The author gives a recapitulatory résumé in the form of resolutions of the four lectures and the subsequent discussion during the Stoker Lectures on 26 March 1982. The inter-dependence of Philosophy, subject philosophy and specific disciplines has the result that

- none of these may over-estimate itself and consequently under-estimate the others;

- a waterlight division is impossible seeing that scientists from all these fields within the context of science are often involved with issues which overlap the fields of the others;

- the religious bias and the specificity of all science have lo come to expression in spite of the distinction between Philosophy, subject philosophy and specific disciplines; and

* subject philosophy constitutes the bridge which makes possible twoway traffic between Philosophy and subject disciplines.

Die doel van hierdie stellings is om in 'n vingerhoed die vier lesings en die bespreking daarvan te probeer saamvat. Wat presies is nou die betekenis van die Filosolic vir die wetenskappe? Dit gaan vanaand dus nie oor die omgckeerde vraag: Wat kan die ander wetenskappe die filosofie leer nie?

Die aandag sal veral gevestig word op die punte waarour ek dink dat ons saamstem. Nie dat ek dink dat die punte waarop ons ooreengekom het om te verskil, nie belangrik is nie. Hierdie verskilpunte hoort egter op die agenda van toekomstige samesprekings.

Dit is nogal 'n opdrag om tydens die aanhoor van die inleiding die groot verskeidenheid van gedagtes sistematies tot 'n eenheid saam te vat. Ek het nie uit eie vrye wil aangebied om die nie benydenswaardige opdrag te verrig nie - ek het opdrag ontvang om dit te doen en vind my half in die posisie van die lilosoof wat - soos gewoonlik - laat gekom het vir'n filosowekongres. Voordat hy daar aangeland het, het die kongres. gangers mekaar alreeds so in die hare gevlieg oor die kwessie van die vrye wil dat hulle besluit het om maar liewer in twee afsonderlike groepe verder te vergader: die deterministe in een saal en die indeterministe in 'n ander.

Koerw, 47(2) 1982 


\section{Van Niekerk}

Toe die laatkommer by die een saal aanklop (dié van die deterministe) en vra of hy maar kan inkom, was die cerste agterdogtige vraag: "Wie het jou gestuur?" "Niemand het my gestuur nie. Natuurlik het ek uit my eie vrye. wil kongres toe gekom!" Dit was egter genoeg vir die deterministe: "Dan hoort jy nie by ons nie maar by die groep in die ander saal!"

Toe hy by die ander saal aankom was die eerste vraag van die indeterministe: "Het jy uit eie vrye wil hierheen gekom?" Salig onbewus van wat aan die gang was en voor sy aankoms reeds afgespeel het, dag die onnosele filosoof hy sal maar liewer nie weer sê hy kom uit eie vrye wil nie. "Nee, ek is hierheen gestuur deur...". Voordat hy egter sy sin kon voltooi, word ook die saal se deur in sy gesig toegeklap!

Die enigste rede waaraan ek kon dink waarom juis ek die resolusies moes opstel, is (soos dic 'Tswanaspreuk lui) 'n bobbejaan nie bewus is van sy lelike snoet nic of (soos die Xhosas sê) 'n muishond (gclukkig!) nie van sy cic aroma bewus is nie!

Aangesien filosowe graag hulle filosofiese vryheid gebruik "to study the facts and draw their own confusions," moet $u$ asseblief help as te veel van my eie siening na vore kom en die standpunte van die sprekers dalk nie korrek weergegee word nie.

Aangesien sewe die getal van die volheid is, volstaan ek met die volgende sewe stellings. Hiewel drs. P.J. van Niekerk se inleiding die laaste gelewer is, begin ek met sy algemene inleiding oor die waarde van die Filosofie om daarna le kom by die locpassing daarvan op die gebied van beroepsopleiding, die Ekonomie en die 'Teologie.

\section{STELLINGS}

1. Die ecrste stelling is negatief: Ons verwerp

- die gedagte dat ecn wetenskap wetenskapliker of nutliger as 'n ander sou wees;

- die vrugtelose getwis oor wie die koningin en wic die diensmaagd(e) in die huis van die wetenskap is;

- die opvatting dat cen wetenskap alleen of by uitstek Christelik sou wces en dat die ander vir hulle Christelike karakter van een wetenskap afhanklik sou wees;

- die beskouing dat 'n wetenskap as sodanig uit die bose en clus die 
vader/moeder van alle ket terye is, of, anders gestel: dat die sondeval net in die een vak sou plaasgevind het!

- dic veronderstelling dat elke wetenskap geïsolecrd agter sy cie ystergordyn kan bestaan in plaas daarvan dal dit nel' $n$ dun kantgordyntije is wat die vakke onderskei (onderskeidling en nie skeiding nic is die regte weg).

2. Die geskiedenis toon aan dat die verskillende wetenskappe

- nic net uit dic filosolie ontwikkel het nie

- maar clat dic filosoliese vader ook na die mondigwording van die verskillende wetenskappe nog steeds invloed op hulle het en hulle graag wil - en kan - help.

Die volgende iwee redes kan vir hierdie filosoliese beinvloeding aangegee word:

- Alle wetenskappe is aan lewensbeskoulike invloede onderworpe. Aangrsien die filosofie ju is onder andere ook die wetcnsk aplike uiddrukking van 'n bepaalde lewens- en wêreldbeskouing is, sal dil noodwendig op dic ander dissiplines invlocd hô.

* Filosolie bestudecer in die certe plek dic snmehang van die groot verskeidenheid in die werklikheid, terwyl die ander wetenskappe elkeen primêr op 'n faset van die ryke verskeidenheid toespits. Die nic-filosoliese wetenskappe moeı egter ook die verskynsels (bimne hulle terreine van ondersock) se verband(e) met die geheel ondersoek. '" (Onderdecl kan nic reg geken word indien dit nie in sy samehang met dic gelieel bekyk word nie. (Hicrmee word natuurlik nie ontken dat die gelieel ook nie sonder sy dele reg begryp kan word nie.) (Op hicrdic pum kan die Wyshegecte (wat veral in dic sameliange geïnceressecrel is) dic ander vakke dus van luulp wees of - as u wil - be:̈nvloed. (Die omgekeerde. invloed/hulp, ul. dić van die ander welcnskappe op dir Pilosolie, worcl nie hiermec onken nie, maar dit gaan nie tans daaroon nic.)

3. Dil is helangrik om die molgende le onderskei (sonder om If skei) en nie te spenear nie: religie, lilosolie, vaklilosolie en vakwetenskap. Dit kan mel die beclel van 'n boom verduidelik word: die penwortel (religic), die stan (die filosolie waarin alles nog cén is), die takke (die vakfilosofieç) en dic vrugte (die vakwetenskappe)). Die religie is die wortel, oorsprong. Die lilosofic gec dic totaalb)ik (sonder om tolalit aristics te wces). Dic filosolic is die twrerigtingskakel tussen die Filosolie en die vakwetenskappe. Die vakweıcnskappe bied 


\section{Van Niekerk}

die konkrete vrugte: 'n heerlike lemoen, appel, perske, druif ens. (Soos alle beclde klop hierdie beeld nie: in alle opsigte nie!)

'n Beter beeld, wat later tydens die bespreking na vore gekom het, is myns insiens dié van 'n huis met 'n fondament (religie), verskillende kamers (welenskappe) wat deur mure geskei maar met deure (die vaklilosofieë) aan mekaar verbind is, en 'n dak oor die geheel (dic Wysbegeerte)

Indien hierdie onderskeid nie gehandhaaf word nie, kan 'n vakwetenskaplike teorie of selfs die verabsolutering van 'n bepaalde vak (sg, -isme) byvoorbeeld maklik vir 'n filosolie aangesien word!

4. In die lig hiervan kan dic filosofie onder andere die volgende hulpdienste aan die ander wetenshappe lewer:

- Dit kan helpoun diepleh en onderlinge samehang van die wetenskappe in die ensiklopedie van dic wetenskap aan te dui. (Wat ekonomie of teologie is, is nie net 'n ekonomiese/teologiese vraag nie. Om te kan bepaal wat ekonomies/teologies is, moet 'n mens 'n geheeloorsig hê en byvoorbeeld weet wat nie-ekonomies of nie-teologies is!)

- Die lilosolie kan as integrerende, samebindende faktor optree, sodat (onder andere as gevolg van voortgaande spesialisasie) die geheelvisic nie verlore raak nie en die universiteit (universitas scientiarum) 'n multiversiteit word - fabrilisering volgens K.J.P.

* Wyshegeerte kan as kritiese geuete funksioneer deur byvoorbeeld I. die verskillende welenskappe aan te spoor om oor hulle voorveronderstellings, basiese uitgangspunte, doelstellings ens. na te dink en 2 . te waarsku teen die verabsolutering van die eic vakperspekt ief en rlaardeur in -ismes (bv. ekonomisme, teologisme) te verval.

5. Met betrekking tot die re'aarde wan die Filosofie spesifieh vir beroepsopleiding (inleiding van drs. J.J. Venter) lê ek die volgende stefling ter oorweging voor:

- Die toenemende professionalisering van die universiteit moet nie negatiet beveg word nie, maar dit moet deur die Filosofie (en ander nie brood-en-boltervakke) eerder positiel as 'n nuwe geleentheid benut word. Professionalisering maak Filosolie nie nutteloos nie maar eerder nog noodsaakliker. I )ie rede hiervoor is veral dat dir tegniese vaardighede 
in ons so snel veranderende samelewing baic gou verouderd en onbruikbaar word. Dic basiese wysgerige perspekt iewe bly cgter. Iin dit is juis vir hicrdic diepste filosoliese vrae/probleme (oor bv. die mens, dic sin van arbeirl, gesag, mag, verantwoordelikheid, geregligheid ens.) waarop die professies vandag in toenemende mate ged wing word om antwoorde te gee. (Dic berocpslui kan nie meer nct vra "Hoe doen ek icts?" nie maar "Waarom doen ek dit, waarmee is ck cintlik besig?")

- Onderrig in die Filosolie sal egter krities bekyk moet word en heel waarskynlik grondig herstruktureer moet word, sodat:

- dit selfstandig, kreatiewe denke as oogmerk het en filosolie nie ter wille van Filosolie (as vak) gedoseer en bestudecr word nie (leer filosolecr en nic net Filosolic leer nie!);

- 'n interdissiplinêre aanpak tot stand kom;

- 'n Christelike akademiese gemeenskap warin 'n oop gees tussen wetenskappers ontwikkel;

- gerugstcun deur'n sinpaticke universiteitsowerheid wat, Ien spyte van probleme (soos vol leerplanne, roosierprobleme en die streng beperkende cise van beroepsverenigings) die Filosolie die geleent heid sal bied om ook sy beskeic bydrac lot beroepsopleiding te lewer;

- filosofie ook vir tegniese kolleges uiters belangrik word.

6. Met betrekking tol die uaarde van die Filosofie spesifiek itr die Lkonomie, nader Bedryfsrekeningkunde gec ek dic volgende stelling ter oorweging:

'n Christelike lilosofie kan hier 'n beskeic diens lewer (inclien diu die produksicproses verstaan) om 'n normatiewe ekonomic te liclp skep as dit inel die agtste gebod ("Jy mag nic stcel nic") as uit gangspunt begrippes soos "brhoefte (bevrediging)", "koste", "waarde" cn "doclmatigheid" 'n eic inhoud kan gec.

7. Met betrekking tol die unarde wan die Filosofie spesifiek uir die Tenlogie (inleiding van prof. J.C. Coctzec) lui my stelling soos volg:

Filosolic kan vir die 'Teologic sowel gevaarlik as heilsaam wees, dit kan dic 'l'cologie help maar ook verlei. Uit die geskicdenis van dic anticke en moderne tcologicë blyk dit 


\section{Van Niekerk}

* dat ook al wou stekere teoloẻ hulle nie met die filosofie bemoei nie, verskillende filosolieë wel deeglik hulle invloed op die teologieë gehad het;

* dat hierdie wysgerige beinvloeding soms onbeuns maar dikwels ook bewus plaasgevind het - soos byvoorbeeld daaruit blyk dat 'n afgeleefde filosolie vir 'n jongere modefilosolie die teologiese huis uitgesit is (vgl. die geval deur prof Coetzee genoem waar die vroeëre Heidegger vir die latere Heidegger verruil is!);

* dat die kontak tussen Filosolie en Teologie nie net op formele vlak plaasgevind het sonder dal die filosolie ook die teologie inhoudelik beïnvloed het nie (dit teenoor diegene wat beweer dat die Filosolie die T'eologie alleen kan help in die sin dat dit tot helderder begripsvorming of die vorming van mue teologiese begrippe 'n bydrae kan lewer);

* dat die invloed ook nie net tot sehere teologiese vakke (soos byvoonbeeld die Dogmatiek, wat van filosolies swaar gelaaide begrippe byvoorbeeld "substansie", "wese", "persoon" ens., gebruik gemaak het) beperk was nie - dit blyk vandag ook duidelik op die gebied van die hermeneutiek en eksegese.

- dit blyk vir die (\%instelike teoloog dalh beter te wees om liewer die geselskap van 'n Cihristelike filosofie op te soek as on te maak asol liy die liilosolie nie nodig het nie - en homsell dalk aas 'n "chance philosophy" uit te lewer (Whitehead)!

* Hoewel gewoonlik gedink word dat die geskiedenis van die Filosolie ant ik wariese werk is (ou kocie uil die sloot van vervloe ecue grawe!), is dit volgens prof. (oetzee juis van die allergrootste belang in dle opleiding van aanstaande teoloë, sodat hulle hulle vak grondig kan peil.

Hoewel dit nie in die lesings daaroor gegaan lıet nie, moet aan die ander kant ook gestel word dal, aangesien die Christelike 'Teologie: so na aall die Bron van die I, ig staan (die Skrif as sy tetrein van ondersock), dit op sy beurt van ontskathare waarde $k$ all wees vir' $n$ lilosool (in casu enige wetenskaplike) wat "in U lig" wetenskap wil beoefen.

\section{Sl.( ')'}

1)it is vir my (uit die lesings en bespreking) duidelik dat die vakwetenskappe 
Filosofie en die ander wetenskappe

nie sonder die Filosofic nic en die Filosofic ook nie soncler dic vakwetenskappe kan klaarkom nie. (Om 'n goeic wetenskaplike te kan wees moet jy ook kan filosofece, met ander woorde insig in die diepere vrac en probleme hê. En on 'n goeie filosoof te wees - cn enige betekenis vir die wetenskappe te hê - moet jy ook kan spesialisecr.

Dic Filosolie moct daartecn waak om hom self te oorskat. 'n Mens mag byvoorbecld nie dic Filosofie (as onmishare middelares) tussen die (Christelike) religie en die vakwetenskappe insknif nie. Filosofie is nie die waarborg vir gocie - of slegte! - wetenskap nie.

Aan die ander kant het dit ook baie duidelik geblyk dat dic vakwetenskappe. nie die invloed van die Filosolie mag onderskal nic.

Vir philosophin regina scientiarum (dic Filosolic as koningin van die wetenskappe) is daar in 'n Reformatoriese wetenskapsloskouing nie plek nic. Vir philosophin ancilla srientianum (Filosolic as cliensmaagd) is dlaar egter volop) ruimte! 